\title{
AGRO-BIO-TECHNO PARK AS AN INNOVATIVE FACTOR OF INCREASING COMPETITIVENESS OF AGRICULTURE UNDER GLOBAL CHALLENGES
}

\author{
Ayrat VALIEV, Kazan State University of Agriculture, 420015, Karl Marx st, 65, Kazan, Russian, ayratvaliev@mail.ru \\ Andrey DMITRIEV, Kazan State University of Agriculture, 420015, Karl Marx st, 65, Kazan, Russian, edu@kazgau.com \\ Kamil HAFIZOV, Kazan State University of Agriculture, 420015, Karl Marx st, 65, Kazan, Russian, ayratvaliev@mail.ru \\ Ilgiz GALIEV, Kazan State University of Agriculture, 420015, Karl Marx st, 65, Kazan, Russian, ayratvaliev@ mail.ru (corresponding \\ author)
}

Farida NEZHMETDINOVA, Kazan State University of Agriculture, 420015, Karl Marx st, 65, Kazan, Russian nadgmi@ mail.ru

Today developed countries are not just talking about agriculture or agribusiness, but set a strategic goal in developing high-tech and profitable sector of the Bioeconomy as a serious alternative to traditional industries, economies and markets. Modern agriculture and worldwide growth structural change of consumption of food. This factor is directly linked with the global orientation of rural households in the world at improving the productivity of agricultural land, reduction of losses, and increase in food production. The agricultural sector focuses on the production and processing of agricultural products, storage, transportation and sales of finished products. Thus, the agricultural sector requires professionals with expertise and skills relevant to the entire production cycle.

The transition to the Bioeconomy market changed the nature and conditions of agricultural workers.

The article provides a rationale for the necessity of establishment of an agro-bio-techno park in the Republic of Tatarstan as an innovative factor of increasing competitiveness of agriculture in Russia under global challenges. It represents results of analysis of global challenges for development of agriculture, domestic and international experience of setting up and work of techno parks in the universities and the model of the Agro-bio-techno park establishment at the Kazan State Agrarian University.

Keywords: agriculture, techno park, global challenges, new technological paradigm, innovative structure of university, agro-biotechno park, Kazan State Agrarian University

\section{INTRODUCTION}

Agriculture of the Republic of Tatarstan occupies one of the leading positions in Russian Federation. It ranks $4^{\text {th }}$ among other regions of Russia and the first in the Volga federal district in the amount of gross agricultural products.

At the same time, successful solution of strategic tasks of boosting the economic and social development of the Republic of Tatarstan and of conversion of economy to the innovative path directly depends on the efficiency of processes of transformation of scientific knowledge into innovations and their commercialization, from the level of innovative susceptibility of main branches of the economic complex of the country, including the agro-industrial complex.

And here an expected question arises of how to increase the competitiveness of domestic agricultural workers, what development tools are there and what is the best possible way to use them? The article provides a rationale for the necessity of establishment of an agro-bio-techno park in the Republic of Tatarstan as an innovative factor of increasing competitiveness of agricultural sector, gives analysis of global challenges for development of agriculture, domestic and international experience of establishment and work of techno parks and proposes the model of the Agro-bio-techno park establishment at the Kazan State Agrarian University.

\section{RESEARCH METHODS}

The main methods used in this study are: comparative analysis, sociological, simulation and prognostics. The FAO UN documents, reports of the World Economic Forum (Davos) and the international and Russian practice of techno parks establishment have become a methodological basis of the study (FAO..., 2017).

At present Russian economy has found itself to be facing long-term systemic challenges which reflect both world tendencies and internal development barriers.

The first challenge is the increasing global competition which encompasses not only traditional markets of goods, capitals, technologies and labour but also systems of national management, support of innovations and the human development. 
The second challenge is the necessity to secure food safety under the conditions of the population growth - today there are more than $7 \mathrm{bn}$ people living on the planet, to bring into harmony industrial and ecological functions, agricultural landscape, to struggle against diseases and to protect health of a man, plants and animals, to provide sustainable development of rural areas as well as the strive of the population to reach new level of life quality.

The third challenge is that with the exhaustion of the export-raw material model of economic growth the developed countries proceed to formation of bioeconomy based on the use of the latest achievements in the spheres of biotechnologies, information science and nanotechnologies including those in agriculture and other branches. The expected new wave of technological changes of the $4^{\text {th }}$ industrial revolution enhances the role of innovations in social-economic development and decreases the influence of many traditional factors of growth (Global Technology...2006; Schwab, 2015).

The fourth challenge is the growth of well-being in the developing countries and the urbanization that is under way there. The boundary line between the agrarian sector and the industrial one was crossed in 2008. People start moving from villages to towns more and more often and that is why the demand for food exceeds the supply. Experts of the FAO say that the food shortage can cause social conflicts (FAO..., 2017).

The fifth challenge is the increasing role of the human capital as the main factor of economic growth. The level of competitiveness of modern innovative economy is mostly defined by the quality of professional personnel and level of their socialization and cooperation.

The possible defeat in the competitive race for formation of the reproduction core of the new technological paradigm is the main threat as far as the implementation of the scenario of innovative development of Russia is concerned. In its turn, the timely formation of such reproduction core is the prerequisite for transition of our country to the innovative way of development. The world economy shows that in the last decades nearly two thirds of agricultural production growth was driven by the scientific-technical progress. Peculiarities of modern intensification of agricultural production lie in the qualitative change of resources, which enables to increase the efficiency of their use significantly. Today the developed countries talk not just about agriculture or agribusiness but set strategic goals of establishment of the high-end and profitable sector of bioeconomy as a serious alternative to traditional branches of economy and markets (EU Framework... 2020). Preservation of Russian agribusiness competitiveness under global challenges and transition of the developed countries to the 4.0 technological paradigms as well as the reduction of the innovative cycle duration are becoming imperative necessity.

The Strategy of innovative development of agribusiness of Russian Federation for the period up to 2020 stresses that "... development of institutes and mechanisms of innovative growth presupposes the development of research agrarian universities, scientific and agro-techno parks and other scientific-commissioning organizations and amalgamations for large-scale innovative activity in agriculture". At present Russian Federation has developed and approved a serious legal framework for the establishment, support and growth of techno parks. The possibility to use technological platforms both already approved by Russian government and those still under the formation process plays a prominent part in the agro-techno park establishment (Nezhmetdinova and Shagivaleev, 2014). These platforms are used as a basis for innovative development of agribusiness and first of all include the following:

1. Resource saving and ecological technologies: alternative and bio energy recourses, hotspot and organic farming and etc.

2. Biotechnologies: protection and selection of plants, cloning if forestry, food technologies and etc.

3. Information technologies GIS-technologies, cloud technologies (data bases and control system), computer control systems in agricultural techniques, software and etc.

4. Technical-technological: automation and robotization of multi-operation agricultural equipment and their maintenance complexes.

5. Social technologies: educational, administrative, communicative, cultural and awareness building.

Kazan State University of Agriculture is one of sustainably and dynamically developing universities of the Republic of Tatarstan, providing training of highly qualified specialists for agriculture and forestry in a wide range of specialties (Kurshin etal., 2009). The additional professional education (26 programmes) grows rapidly, including the international MBA programme in Agribusiness (the first one in Russia), which is implemented together with the leading European university of Wageningen (the Netherlands) and the European Association "AGRIMBA".

Kazan State Agrarian University takes the lead in the agricultural scientific-educational cluster in RT the main task of which is the integration of education, science and production, provision of necessary material and technical basis and implementation of progressive high-end technologies into agricultural industry. It successfully and fruitfully develops scientific- technical and innovative focus areas in plant growing, cattle breeding and processing industry which make provision for transfer to new technologies, modern technical means, system of adaptive intensification of agriculture and progressive forms of social-economic relations. Developments of scientists of the university are widely implemented in agribusiness enterprises and the amount of scientific grants, won by the university, has doubled in the last two years. There is an established innovative infrastructure which comprises five small innovative enterprises, three scientific laboratories on advanced technologies, four innovative centres including those that are unique in Russia. Together with leading representatives of agribusiness and Tatarstan Ministry of Agriculture, the university set up a unique customerapplication center. The geography of international cooperation of the university in academic mobility, internship and scientific work is growing from year to year, including the USA, Canada, Great Britain, Denmark, the Netherlands, Switzerland, Finland, Sweden and other countries.

Kazan State Agrarian University was one of the first among other agricultural universities of Russia to prepare the Strategy of its development for the period up to 2022 approved by the government of the Republic of Tatarstan and 
the World Bank, which defined as one of its long-term priority tasks "modernization of the infrastructure of Kazan State Agrarian University by organization of public private partnership and construction of united academic campus and high-tech agro industrial techno park" (Borisoglebskay, 2011). The initiative of organizing an agro-bio-techno park was supported by the leadership of the Republic of Tatarstan.

\section{RESEARCH RESULTS}

Despite the fact that the history of techno parks is more than 50 years old, currently there is no their common definition or conventional classification. In the beginning of 2002, the international association of technological parks proposed the following definition: "technological park is an organization run by specialists, the main task of whom is the growth of well-being of local community by promoting innovative culture and competitiveness of innovative business and scientific organizations. To reach these goals, the techno park stimulates and controls flows of knowledge and technologies between universities, scientific-research institutes, companies and markets" (Sumyskay, 2007; Avdulov and Kulkin, 2005; Fayzrakhmanov et. al., 2012). This broad definition of a techno park makes it possible to set a minimum list of standards and requirements for seekers of "a technological park" title. The international association of technological parks emphasizes the value equivalence of such notions as "a technological park", "a techno police", "a technological areal", "a research park" and "a science park". In Great Britain they usually use the term "a science park", in the US - "a research park" and in Russia - "a techno park" (Avdulov and Kulkin, 2005).

The State programme from March 10, 2006 "Organization of high-tech techno parks in Russian Federation" says that techno parks in the sphere of high-end technologies comprise "enterprises of high-end branches of economy including branches of nano-, bio-, information and other technologies, scientific organizations and educational institutions, which provide scientific and personnel potential of such enterprises, as well as other enterprises and organizations, the activities of which are technologically related with the abovementioned branches or are used for their maintenance" (State program..., 2006).

A large number of various forms of techno park structures have appeared in the world for 50 years of technoparks history: scientific parks, technological and research parks, innovative, innovative-technological parks, technology transfer centers, business and technology incubators, techno polices. The practice of a scientific park having several founders is wide spread abroad. At the same time, the technical parks which were established with the active participation of the state are most successful. The Chinese experience of setting up techno park zones is interesting in this respect. Up till now 120 techno park zones - half of them with the participation of the state - have been established in China since the first Chinese techno park -Beijing experimental zone of high-end technologies development - was opened in Hainan Province in 1988 (Avdulov and Kulkin, 2005).

In the last two decades such innovative structure is also being formed in the system of university education in the Republic of Tatarstan and this is for a reason. Since 1990 higher education schools of Russia have started organizing techno parks at leading universities, assuming them to be an efficient mechanism of commercialization and transfer of results of universities scientific research to economy. The role of universities in establishment of techno parks has a special emphasis in the State "Organization of high-tech techno parks in Russian Federation" (Nezhmetdinova and Shagivaleev, 2014).

\section{CONCLUSIONS AND DISCUSSION}

Currently we can speak about the successful foreign experience of establishment and work of technoparks in the sphere of "life sciences" on the basis of the 4.0 technological paradigms. It is there that they are most close to the idea of agro-bio-techno park by their technological parameters (Fayzrakhmanov, 2013). Among them one can name: York Science Park (York, England) (biotechnologies, medical technologies, computer technique and periphery), The Science Park CENTURIARIT - Romagna Innovazione Tecnologia (Cesena, Italy)- (agriculture, biotechnologies, electronics and microelectronics, software, logistics), Technologies Park Heidelberg GmbH (Heidelberg, Germany) - (biotechnologies, environmental protection, medical technologies), The Oxford Science Park (Oxford, England) (agriculture, biotechnologies, electronics and microelectronics, software, logistics), The Symbion Science Park (Copenhagen, Denmark) (biotechnologies, internet-technologies, medical technologies) and others.

The establishment of agro- techno parks in Russia is just in its initial stage (Kalimullin, 2013; Galiev, 2015; Faizrakhmanov et. al., 2008). As a rule it is carried out with a substantial support from regional and municipal authorities, large agribusiness holding companies and banks on the basis of consolidation of the agricultural intellectual and educational potential.

Proceeding from the brief analysis of work of techno parks in different countries it is evident that they represent the most efficient infrastructure for supporting innovative activity, namely: "production" of small and average size innovative firms, "growing" entrepreneurs for innovative scientific-technical business, production of innovative technologies and technique, the diversification of economy in regions, commercialization of intellectual property (novelties), the technological transfer and the integration of education, science, production and authorities with the aim of saturating the regional economy with innovations. 
Table. 1. Russian agro-technoparks (2012).

\begin{tabular}{|c|c|c|c|}
\hline The name of an agro-techno park & Region & State & Cost \\
\hline $\begin{array}{l}\text { Innovative agro-bio-techno park of the } \\
\text { Republic of Tatarstan }\end{array}$ & Republic of Tatarstan & Planned & Up to 3 bn roubles \\
\hline Green Valley & Tambov region & Planned & 35 bn roubles \\
\hline Agro-techno park Sibirskiy & Novosibirsk region & Planned & 3 bn roubles \\
\hline Agro-techno park & Saratov region & Planned & 8 bn roubles \\
\hline AgroDagItalia & Dagestan & Planned & 14 bn roublrs \\
\hline Agro-techno park & Republic of Altay & Planned & 1.6 bn roubles \\
\hline $\begin{array}{l}\text { Scientific business center Agto-techno } \\
\text { park "Volgo-Donskoy" }\end{array}$ & Volgograd region & Planned & 2.1 bn roubles \\
\hline Agro-industrial park "Gorodische" & Moscow region & Planned & 20 bn roubles \\
\hline $\begin{array}{l}\text { Educational-scientific innovative center } \\
\text { "Agro-techno park" }\end{array}$ & Belgorod region & In operation & 0.8 bn roubles \\
\hline
\end{tabular}

The conceptual idea of the establishment of the Agro-bio-techno park as part of Kazan State Agrarian University lies in understanding of the fact that it should be an intellectual and technological platform for innovative development of agribusiness on the basis of uniting scientific-educational potential and resources of the leading professional educational institutions, scientific-research organizations, agricultural producers and agribusiness.

The complete logic of global economy development is driven by scientific support, acceleration of practical implementation of new principles and technological approaches in agriculture. Development of innovative agribusiness infrastructure and its human resourcing, establishment of "breakthrough" centers of implementation of high-end technologies in agricultural industry and their commercialization, setting up institutes of rural areas development must become a foundation for technological advance of the country in the sphere of agriculture and food security under global challenges.

\section{REFERENCES}

1. Avdulov, A.N., Kulkin, A.M. 2005. Scientific and technological parks, technopolises and regions of science of 2005. Moscow: INION of RAS.

2. Borisoglebskay, L.N. Influence of science and technology parks in the sphere of high technologies on innovative development of regions of Russia. 2011. L.N. Borisoglebskaya, A.V. Mats. Innovations. pp.58-64.

3. Faizrakhmanov, D.I., Valiev, A.R., Nezhmetdinova, F.T., Krupina, G.D. 2008. Agricultural scientific and educational potential of the Republic of Tatarstan and directions of its development. Vestnik of Kazan State Agrarian University, No. 3(9). pp. 5-10.

4. Faizrakhmanov, D.I., Nezhmetdinova, F.T., Valiyev, A.R. 2012. Agrotekhnopark as an innovative factor of increase in competitiveness of agriculture in the conditions of inclusion of Russia into the WTO. Vestnik of Kazan State Agrarian University, Vol. 3(25), pp. 50-58.

5. FAO. 2017. The future of food and agriculture - Trends and challenges. Rome. Available at: http://www.fao.org/3/a-i6583e.pdf (Accessed on 12/05/2017).

6. Galiev, I.G., Khusainov, R.K. 2015. Assessment of functioning tractors in the agricultural production. Machinery and Equipment for the Village, No. 10, pp. 13-15.

7. Global Technology Revolution 2020, In-Depth Analyses: bio/nano/materials/information trends, drivers, barriers, and social implications. Technical Report. Richard Silberglitt et al. RAND. National Security Research Division. Santa Monica, CA. 2006. Available at: http://www.rand.org/pubs/ technical reports/2006/RAND TR303.pdf (Accessed on 12/05/2017).

8. Kalimullin, M.N., Abdrakhmanov, R.K., Galiev, I. 2017. Improvement of technology of potato cultivation. Machinery and Equipment for the Village, No. 4, pp. 6-9.Schwab, K. 2015.

9. Kurshin, O.A., Nezhmetdinova, F.T., Faizrakhmanov, D.I. 2009. The development strategy of the Kazan state agrarian University until 2022: scientific publication. 2009. Ed. by D. I. Faizrakhmanov. Kazan: Publishing house Academy of Sciences.

10. Nezhmetdinova, F. 2013. Global challenges and globalization of bioethics. Croatian Medical Journal, Vol. 54, Iss. 1, pp. 83-85. https://doi.org/10.3325/cmj.2013.54.83

11. Nezhmetdinova, F.T., Shagivaleev, L.R. 2014. Life and professional strategies graduates of scientific and educational cluster agro-industrial complex of the Republic of Tatarstan (scientific edition). General ed. D. I. Faizrahmanov. Kazan: Publishing house of Kazan SAU, pp. 79-84, 89-95.

12. State program "Creation in the Russian Federation of science and technology parks in the sphere of high technologies". 2006. (The order of the Government of the Russian Federation of March 10, 2006 No. 328-r). [In Russian]

13. Sumyskay, T.V. Functioning of technopolises and science and technology parks abroad and lessons for Russia 2007. Bulletin of NSU. Series Social and Economic Sciences, Vol. 7, Iss. 1. pp. 14-24.

14. The EU Framework Programme for Research and Innovation Horizon 2020 . Available at: http://ec.europa.eu/programmes/horizon2020/en/ (Accessed on 12/05/2017).

15. The Fourth Industrial Revolution: what it means, how to respond. Available at: http://www.foreignaffairs.com/authors/klausschwab (Accessed on 12/05/2017). 